\title{
PUBLIC SERVICE TRANSFORMATION DURING THE COVID 19 PANDEMIC BY THE GENERAL ELECTION COMMISSION OF BANDUNG REGENCY IN THE LOCAL ELECTION (PILKADA)
}

\author{
Tatang Sudrajat ${ }^{1}$
}

\begin{abstract}
${ }^{1}$ University of Sangga Buana, Bandung, Indonesia id.tatangsudrajat@gmail.com This study aimed to elaborate the transformation of services provided by the General Election Commission of Bandung Regency during the Covid 19 pandemic to all election stakeholders in all stages of the election such as voters, political parties, administrators, candidate pairs, election supervisors, election observers, election desks and other parties. It also analysed the substance of all local elections regula-

Submitted: 6 September 2021 Revised: 1 December 2021 Accepted: 5 December 2021 tions as a form of policy for the implementation of local elections during the Covid-19 pandemic. This study used qualitative method with in-depth interview and documentation. The result of this study indicated that there was a transformation of public services that relied on communication and information technology, such as updating voter data, socialization and voter education, nomination of candidate pairs, campaigning, as well as voting and counting votes.
\end{abstract}

Keywords: public service; local head election; Covid -19; transformation

\begin{abstract}
ABSTRAK
PStudi ini bertujuan untuk mengelaborasi transformasi pelayanan yang diberikan KPU Kabupaten Bandung selama masa pandemi Covid 19 kepada seluruh pemangku kepentingan pemilu di semua tahapan pemilu, seperti pemilih, partai politik, pengurus, pasangan calon, pengawas pemilu, pemantau pemilu, dan pemangku kepentingan lainnya. Selain itu juga menganalisis substansi seluruh peraturan pilkada sebagai bentuk kebijakan penyelenggaraan pilkada di masa pandemi Covid-19. Studi ini menggunakan metode kualitatif dengan wawancara mendalam dan dokumentasi. Hasil penelitian menunjukkan adanya transformasi pelayanan publik yang mengandalkan teknologi komunikasi dan informasi, seperti pemutakhiran data pemilih, sosialisasi dan pendidikan pemilih, pencalonan pasangan calon, kampanye, serta pemungutan dan penghitungan suara.
\end{abstract}

Kata Kunci: pelayanan publik; pemilihan kepala daerah; Covid 19; transformasi

\section{INTRODUCTION}

The Covid -19 pandemic has had a very broad impact on various aspects of human life, including politics and government affairs. The direct election of local heads (pilkada) in Indonesia, which has been taking place since 2005, during the 2020 simultaneous local elections, was carried out under conditions of uncertainty due to the Covid -19 pandemic. Therefore, all governors, regents, and mayors in 270 regions Indonesia takes place under strict health protocol arrangements as set by the government.
The discussion of local election regulations will not be separated from the discussion of general elections. This was not only related to the people's right to make choices in choosing a leader as an indicator of democracy, but also to the existence of the General Election Commission (KPU) nationally. The duties, authorities, and obligations of the KPU in the implementation of local elections were stated in Article 9 of Law Number 1 of 2015 concerning the Stipulation of Perppu Number 1 of 2014 concerning the Election of Governors, Regents, and Mayors into Laws. 
The relationship between the responsibilities of the local election administration was stated in Article 8 paragraph (1) that the election administration was the joint responsibility of the KPU, Provincial KPU and Regency/Municipal KPU. The election in Bandung Regency to elect the regent and deputy regent in 2020 was the fourth time after 2005, 2020, and 2015. The national election was based on KPU Regulation Number 15 of 2019 concerning Stages, Programs and Schedule for the Election of Governor and Deputy Governor, Regent and Deputy Regent and/or Mayor and Deputy Mayor in 2020, and in Bandung Regency based on Bandung Regency KPU Decree Number 65/PP.01.2-Kpt/3204/ Kab/IX/2019 concerning Technical Guidelines for Stages, Programs and Schedule for Election of Regent and Deputy Regent of Bandung year 2020.

The implementation of this election was basically an activity that contains public services. This was because election stakeholders, including voters, political parties, candidate pairs, election supervisors, observers and other election stakeholders need to fulfil their needs as interested parties in accordance with their position and role in the elections. For example, voters were very interested in various adequate information from the local election organizers on the figures of the pairs of candidates who will compete. In addition, he has an interest in being able to channel his political aspirations at polling stations by first ensuring that he has been registered in the permanent voter list. Public services according to Article 1 point 1 of Law Number 25 of 2009 concerning Public Services were activities or series of activities in the context of fulfilling service needs in accordance with laws and regulations for every citizen and resident of goods, services, and/or administrative services provided by the organizer public service.(Rulinawaty et al., 2021)

The holding of local elections during the Covid -19 pandemic was of course very different from the three previous local elections. In other words, the services provided by The KPU of Bandung Regency were also an adjustment step to this condition. There were big demands and challenges for The KPU of Bandung Regency to provide the best service, along with major changes as implications of the Covid -19 pandemic.

Nationally, the KPU has issued several policies in relation to the Covid -19 pandemic such as Regulation Number 6 of 2020 concerning the Implementation of the Election of Governors and Deputy Governors, Regents and Deputy Regents, and/or Mayors and Deputy Mayors Simultaneously Continued in Conditions of Corona Virus Disease 2019 (Covid -19) Non-Natural Disasters which were later amended by KPU Regulations which was then changed to Number 10 of 2020 and KPU Regulation Number 12 of 2021.

This research aims to elaborate on the transformation of services provided by The KPU of Bandung Regency during the Covid 19 pandemic to all election stakeholders in all stages of the election. Stakeholders of this election were voters, political party administrators, regional head candidate pairs, election supervisors, election observers, election desks and other parties. In addition, it also analyzes the substance of all local elections regulations as a form of policy for the implementation of local elections during the Covid-19 pandemic.

\section{RESEARCH METHOD}

The research used qualitative methods combined with normative juridical methods. Qualitative methods were used to obtain primary data through in-depth interviews with the KPU of Bandung Regency Chairman and his staff, as well as other election stakeholders. These include Supervisory Agency/Bawaslu, campaign teams for candidate pairs, monitoring/survey institutions, and PPK. Secondary data was carried out using documentation techniques through the collection and analysis of all printed and digital data according to the research topic in various forms. The normative juridical method was used by collecting and analysing all regulations/legal products, in the form of regulations and decisions, issued by the Commission of Election / KPU and the KPU of Bandung Regency.

\section{RESULT AND DISCUSSION}

\section{Services of Local Election Stage}

Based on Article 1 point 1 of Law Number 25 of 2009, the types of services provided by The KPU of Bandung Regency as local election organizers and public servants, including services and administrative services, were provided to members of the public in general, as well as to certain parties, such as candidate pairs, team members 
Public Service Transformation During The Covid 19 Pandemic by The General Election Commission of Bandung ... Tatang Sudrajat

campaigners, election supervisors and election observers. The services provided by The KPU of Bandung Regency directed to the political parties, prospective pairs of candidates/candidates and other stakeholders relate to several stages of activities that have been stipulated in the Decree of The KPU of Bandung Regency Number 65/PP. 01.2-Kpt/3204/Kab/IX/2019.

This stage includes secretarial and public information, services for the preparation and determination of technical guidelines, registration services for prospective candidates and aspects, services for forming adhoc election officials/ agencies at the sub-district level to TPS, campaign preparation services and their aspects, voter registration services, registration services for monitoring/survey/quick count institutions, logistics preparation and distribution services, voting and vote counting services, election results dispute services, as well as services for ratifying elected candidates.

The election stages which have started since September 2019 were delayed for three months due to the Covid-19 outbreak. However, the launching of the local elections was held on March 8, 2020 entitled "Bandung Regency Election Medal 2020" at the Si Jalak Harupat Stadium, which was marked by the planting of tree seedlings in the stadium yard, in accordance with one of the election themes, namely PEPELING (Environment Care Election). Nationally, the Covid-19 outbreak has impacted voting day, which was originally scheduled for September 23, but was postponed to December 9, 2020. The local election with the mascot "Si Mantul" (Si Leopard) and the jingle "Ulah Hilap ka TPS" along with messages Covid-19 prevention was part of the voter socialization and education activities carried out at each stage of the election activity.

\section{Service to Implementers of Adhoc Elec- tion Agency}

Internal services to fellow organizers, especially those who were ad-hoc at the sub-district, village and TPS levels have been carried out since their recruitment as election administrators. The stages of forming PPK and PPS were carried out before the Covid-19 outbreak, while PPDP and KPPS were after the outbreak. Additional requirements for the SWAB/PCR test as well as the requirement not to have comorbidities for PPDP and KPPS candidates were implemented to ensure that clusters of distribution do not arise due to the pilkada as feared by some. Most of the registration and selection were done online, except for certain areas which, due to certain technical constraints, were carried out offline implementing strict health protocols. Overall, the number of members of the adhoc local election organizing committee involved were 155 PPK members, 840 PPS members, 6.869 PPDP and 48.118 KPPS members. This number does not include PPK secretariat staff who were government employees in each sub-district and PPS secretariat staff in each village.

Internal service providers in the form of increasing technical capabilities were carried out to members of PPK, PPS, KPPS and PPDP in the form of technical guidance/training and coordination meetings were carried out offline with face-to-face selectively considering the urgency of the type of training according to the level of activity stages because it was related to the operation of the system information. To further strengthen and deepen the material to participants, it was then carried out online. The materials presented included voter data collection with the Voter Data Information System (Sidalih), and vote counting recapitulation with the Recapitulation Information System (Sirekap).

In a pandemic condition, to ensure the readiness of adhoc implementers in carrying out their duties, collaboration between The KPU of Bandung Regency and the Health Service was carried out, especially to assist in handling health protocols. Among them were for the implementation of SWAB/PCR and rapid tests for all levels of adhoc implementers. In this context, from November 26 to December 1 2020, a rapid test was carried out on 61,866 KPPS members and security for TPS in each sub-district and village, in collaboration with The Bandung Regency Office of Health.

\section{Secretarial Services and Public Informa- tion}

Secretarial services were an element of supporting staff for the smooth running of all stages of the election. The arrangement of documents for the entry and exit of the local election organizers was also supported using informati- 
on systems and the availability of the local election organizer's website which was updated at any time in accordance with the development of the election stages. Likewise, the service of the public's right to information in accordance with the regulations on public information disclosure was facilitated by the existence of a public information manager. Various groups of people who need information receive services according to the type and level of their needs.

This was in line with what Rosenblomm (Rosenbloom, Goldman, \& Ingraham, 1994). stated which states that there were six trends in government transformation. Among other things, he stated that open, integrated technology infrastructures foster collaboration and the creation of services to meet evolving needs, enabling governments to deliver the right service, at the right place and time. In regard to citizens, it was further stated that over the internet, citizens were connected to one another and to government agencies as never before. The nature and course of citizen involvement in government was changing rapidly.

Services for information needs during elections must be prioritized because hoaxes were very dangerous for the success of targeting information about elections. Bahriyah and Ahmad Sururi Afif stated that the emergence of fake news and fake news in the mass media, hate speech, SARA statements, and eliminating the right to vote were vulnerable and easy to happen in the current era of social media and online technology(Bahriyah \& Afif, 2021)

\section{Voter Data Update Service}

Services to the community were related to updating voter data, including making Bandung Regency the host of the Matching and Research Movement / Simultaneous Coklit in the 2020 simultaneous elections, which was attended by the Chairperson of the Indonesian KPU. This was a ceremonial activity that marks the PPDP's matching and research of candidate voter data to every resident's house, which was carried out completely with strict health protocols. PPDP in carrying out their duties was equipped with complete personal protective equipment, including masks, face shields, and hand sanitizers. The implementation was carried out outside the house, not inside the house to reduce physical contact to prevent the spread of Covid-19.

To improve the quality of data updating services, apart from going through the DPS and DPT phasing stages, previously a DPS Public Exam was also conducted, as a means for organizers to get suggestions and improvements to the voter list to make it more accurate. What the organizers do to conduct a public examination of the DPS, in the context of a democratic country that places relations with the people as essential, was none other than to give satisfaction to the people as owners of sovereignty. The state through its apparatus, including in the implementation of local elections, provides services to the people as the giver of the mandate. Service from an institution to another party was basically a service. In this regard, according to Tjiptono, service was an activity, benefit or satisfaction offered for sale, which has four characteristics, namely intangibility, inseparability, variability, and perishability (Tjiptono, 2005).

Within this framework, data updating was also carried out in prisons and detention centers, which was carried out by implementing health protocols. The provision of services by administrators without discrimination to all citizens was a tangible manifestation of a democratic-law state that must be the concern of public administrators, including election and regional head elections. From the perspective of the New Public Management paradigm in public administration, as stated by J.V. Denhart and R.B. Denhart that one aspect that must be considered was serving rather than controlling (serve rather than steer) in relation to the position and role of the administrator (Rewansyah, 2010)

Based on a series of data updating activities, the DPT was set at 2.356.412, which was determined by the Decree of The KPU of Bandung Regency Number 220/PL.02.1-Kpt/3204/ $\mathrm{Kab} / \mathrm{X} / 2020$. This data serves as the basis for the organizers to determine various needs that reflect services to the public, including the number of polling stations, the number of logistical needs including Covid-19 prevention tools, as well as the need for the number of documents for polling and counting votes.

\section{Candidate Pair Registration Service}

In accordance with the provisions, prospective pairs of candidates can come from poli- 
tical parties/a coalition and pairs of individual candidates who were supported by members of the public by attaching a photocopy of their ID card. The registration service for individual candidate pairs takes place over a long period of time. Prospective candidates must be supported by at least 153,443 voters, spread over at least 16 sub-districts. The service mechanism for submitting administrative documents, especially evidence of support in the form of photocopies of ID cards to prospective candidates, was carried out with a nomination information system.

This continues with administrative verification by the organizers and factual verification by PPS officers. This factual verification was carried out to clarify and confirm the truth or validity of the support stated in the document by following strict health protocols. Until the final stage of the nomination mechanism, which among other things was marked by the existence of a nomination dispute through the Bandung Regency Supervisory Agency/Bawaslu by the prospective pairs of candidates Lili Muslihat and Wida Hendrawati, not a single candidate pair met the requirements.

As part of the service for local elections, to provide information on all aspects related to nominations by political parties/combined political parties, a road show was held to all political parties that have seats in The DPRD of Bandung Regency. The political parties were the PKB Party, the Gerindra Party, the PDIP Party, the Golkar Party, the Nasdem Party, the PKS Party, the PAN Party and the Demokrat Party. The activity was carried out in compliance with strict health protocols.

On Friday, September 4, 2020, the registration of candidate pairs from political parties was carried out at The KPU of Bandung Regency Secretariat by following the health protocol. Supporters, community members and other parties who were unable to attend due to health protocol reasons, were provided with facilities through live broadcasts by the organizers through social media. The activity of receiving registration files for prospective pairs of candidates was followed by research on the validity and completeness of documents, both administratively and factually.

There were three pairs of candidates determined from the political party line, namely the Hj. Kurnia Agustina - Drs. Usman Sayogi YB, M.Sc., supported by the Golkar Party and the Ge- rindra Party, the pair of Hj. Yena Iskandar Masoem, S.Si.Apt - Atep, supported by the PDIP Party and the PAN Party, and H. Dadang Supriatna, SIP, M.Si.- H. Sahrul Gunawan, SE, supported by the PKB Party, Demokrat Party, Nasdem Party, and PKS Party.

Services related to the stage of drawing the serial number of the candidate pair will be held on September 24, 2020 at the Sutan Raja Hotel Soreang, with health protocols. Supporters and other community members who were unable to attend were facilitated with social media broadcasts. In this event, the signing of an integrity pact was also carried out, including to comply with and implement health protocols and to realize peaceful, integrity and democratic local elections.

\section{Campaign Service}

The provision of information services on stages, types of campaigns, prohibitions and sanctions during the campaign period was carried out in various media. The campaign, which has been carried out since September 26, 2020, includes the types of limited meeting campaigns, face-to-face and dialogue, distribution of campaign materials, installation of props and other activities. There were also campaigns facilitated by the organizers in the form of public/open debates between pairs of candidates, as well as campaigns through mass media, print and electronic. The campaign props and campaign materials include, among others, the vision, mission and work program of the candidate pairs that can be conveyed to voters.

Local election organizer services provided facilitation for printing campaign props and determining the location for their installation. These props were in the form of billboards measuring $3 \times 5 \mathrm{~m}$ for each pair of candidates, 560 banners measuring $1 \times 6$ meters for each pair of candidates, and banners measuring $0.5 \times 4 \mathrm{~m}$ for 155 for each pair of candidates. The location for the installation of campaign props was determined by the organizers based on recommendations from the Bandung Regency Government, as well as information on locations/places that were prohibited as places for installing campaign props. In addition to campaign props facilitated by the organizers, each pair of candidates was also allowed to print their own, provided that a maximum of $200 \%$ of the amount provided by 
the organizers was allowed. In addition, the socialization of the candidate pairs was also facilitated through videotron for 14 days.

Other services from the organizers also facilitate the provision of campaign materials given to candidate pairs, namely flyers, brochures, pamphlets, and posters, to be distributed to the public. In addition, candidate pairs/campaign teams can also prepare their own campaign materials in other forms, such as clothing, head coverings, eating/drinking utensils, calendars, business cards, pins, stationery, umbrellas, and stickers. Also, the manufacture of equipment related to the prevention of Covid -19 such as masks, gloves, face shields and hand sanitizers.

The service and facilitation of the organizers were also carried out in the form of three public debates. First, with the theme "Improving Service and Community Welfare of Bandung Regency", on Saturday October, 31, 2020. Second, with the theme "Improvement of Development and Resolution of Regional Problems and Synergy of Bandung Regency and National Development in the Framework of Strengthening the Unitary State of the Republic of Indonesia”, on Saturday, November 14, 2020. Third, with the theme "Strategies for the Eradication of Drug Abuse and Handling the Covid 19 Pandemic in Bandung Regency”, on Saturday, November 28, 2020.

Candidate pairs can also take advantage of campaigns or display campaign advertisements through social media with a maximum of five contents per day, and through online media as many as five media that have been verified by the Press Council. The material displayed is narrative, graphic, character, interactive, or non-interactive, and can be received by the recipient's device. The period of broadcasting was from November 22 to December 5, 2020. The use of social media for campaigns was right in the era of the industrial revolution 4.0 and society 5.0 today. Widhiasthini said that disruption, which was interpreted as a change towards digitalization, the abandonment of old patterns into new patterns, was very clearly seen in the selection of social media and online media as the main campaign method (Widhiasthini, 2020).

The organizers also provide services to candidate pairs for campaigning in the mass media such as television, radio, and print media. Print media that became partners of the organ- izers were the Pikiran Rakyat newspaper, Galamedia, Tribun Jabar. The television and radio media consists of West Java INews, West Java MNC, West Java Kompas, Bandung TV, PJTV, Dahlia radio, I-Radio and PR FM. For campaign advertisements in online media, the organizers collaborate with the media timeindonesia.co.id., dara.id., and visi.news .

Services by the organizers were also provided in the form of controlling campaign props and campaign materials as a sign of the end of the campaign period on December 5, 2020, and the start of the quiet period on December 6 for three days until December 8, 2020. Symbolically, with the support of Supervisory Agency/Bawaslu, National Army/TNI, The National Police, The Police of Local Government/Satpol PP and other elements have taken down/removed several campaign props that were installed during the campaign period in several places, including billboards, posters, banners, and stickers. The organizers have also asked the campaign team to deactivate their social media accounts once they enter a period of no campaign.

The important thing from the form of service is the technical guidance on campaign funds and communication between organizers and the campaign team of the candidate pairs regarding the Initial Campaign Fund Report, Campaign Fund Donation Receipt Report, and Campaign Fund Revenue and Expenditure Report. This incoming source of funds which is in accordance with the election regulations, and information technology device called the Campaign Fund Information System (Sidakam).

\section{Voter Education and Socialization Ser- vices}

In relation to the stages of socialization and voter education, since the outbreak of the Covid-19 March 2020 outbreak, the public services carried out by the organizers were not only about the importance of the local election and its implementation techniques, but also intensively socializing the prevention of epidemic transmission. Local election themes were combined with epidemic prevention themes, for example "Together Prevent Pilkada Clusters, Stop the Spread of Covid-19, Wear Masks Correctly, Tips for Facing Families Who Spread Covid-19 Hoaxes". Services provided to community members through media that were used intensively with sociali- 
Public Service Transformation During The Covid 19 Pandemic by The General Election Commission of Bandung ... Tatang Sudrajat

zation props, including posters, brochures, and stickers, especially to community members living in suburban areas and areas with low internet connections.

However, the services provided to voters using the physical face-to-face method were still limited by implementing strict health protocols. These include avoiding crowds, the obligation to wear masks, checking body temperature, wash their hands before entering the room, and maintaining a distance between participants during the activity. This method includes people with disabilities, plantation workers in Pangalengan, representatives of online/gojek motorcycle taxis through the declaration of peaceful elections, among netizens/millennials in Margahayu, as well as novice voters at SMA Negeri 1 Soreang with a webinar.

In addition, limited socialization was carried out to members of Karang Taruna in Kutawaringin District, female voters, members of community organizations and non-governmental organizations, as well as journalists in collaboration with the Indonesian Journalists Association (PWI) and the Indonesian Television Journalistic Association (IJTI).

Likewise, intensive socialization regarding the prevention of Covid -19 was carried out through various available socialization media, namely posters, stickers, and banners. The election organizers require all members of the adhoc agency of election (PPK, PPS, PPDP and KPPS) to utilize their respective social media usage. In addition, collaboration with the Bandung Regency Office of Communications and Information was carried out through the distribution of SMS blasting and audio-visual broadcasts on videotrons located in strategic locations.

Seminars using the web (webinar) either independently or in collaboration with other agencies was helpful as socialization. Some of them were the National Webinar "Measuring the Readiness of the 2020 Simultaneous Regional Elections" in collaboration with FISIP PTS throughout Indonesia on Saturday 11 July 2020, Sawala Political Elections in collaboration with newspaper/HU Pikiran Rakyat on Monday, July 13, 2020, Webinar "Bandung Regency Election: Controlled in the Midst of a Pandemic?" on Tuesday 28 July 2020, Webinar "Examining Simultaneous Pilkada Preparation in West Java”, on Monday, September 7, 2020, Dialogue
"Determination of Candidates and Commitment to Implementing Health Protocols", on Friday, September 18, 2020 in collaboration with Elshinta radio.

Cooperation is also carried out with press/ media associations so that they can further streamline voter socialization and education services, as well as media to prevent the spread of Covid-19. Several things have been done by the local election organizers regarding the transformation of work routines which in line with what Warren Bennis stated that adaptability as a criterion of a healthy and effective organization as the ability to solve problems and react with flexibility to changing environmental demands (Cooper Ph.D. D.Phil., J. Taylor B.Sc. Research Student, Cooper Ph.D. D.Phil., \& G. Fairbum M.D. M.A., 1987)

\section{Voting and Counting Services}

Simulation of voting and vote counting was carried out as well as the use of Sirekap at polling stations with health protocols. This activity was attended by community members/voters at TPS 109 Baleendah Village, on Saturday 21 November 2020. In providing services to citizens during the Covid -19 pandemic, according to national policy, the number of voters at each polling station is reduced, no longer 800 people but to 500 people. The number of TPS thus increased by 990 from the number of TPS during the 2018 governor election, to 6,874 TPS.

At each polling station/TPS, the services provided by the organizers were in the form of information posted around the polling stations, including the list of voters, and the vision, mission, and work program of the candidates. In providing services to certain parties, the election organizers set up 1 TPS at the Bandung Police, which specifically serves the suffrage of Bandung Regency residents who were currently serving a prison term. Voters who previously received an invitation letter/notification about the time and location to cast their ballots at the designated TPS, were given the opportunity to come to the TPS starting at 07.00 local time.

As part of the service during the Covid-19 pandemic, the organizers prepared various facilities in the context of preventing Covid-19 in the form of hand washing facilities, hand sanitizer, tissue, and gloves. Even though in some polling stations the start of the vote counting was not at 
13.00, in general the vote counting was carried out smoothly. The services provided by KPPS works well to witnesses from candidate pairs and Field Supervisors as well as observers and members of society. This is mainly related to access and opportunities to participate in the vote count as well as access to get the results of the vote count.

The service for the recapitulation process in 31 sub-districts scheduled on December 10-14, 2020 is provided by PPK with the support of the PPK secretariat, in the form of invitations/notifications for recapitulation meetings addressed to witnesses from pairs of candidates, the Subdistrict Supervisory Agency/Panwaslu and other parties. The number of PPKs who completed the recapitulation within a day were 26 sub-districts (83.87\%) and five sub-districts (16.13\%) completed in two days.

Services in the recapitulation stage at the district level on Tuesday 15 December 2020 were carried out with strict health protocol procedures. Before the official event begins, the invitees and meeting participants must first fill out the attendance list at the table prepared by the committee by showing their identity. In general, the preparation and implementation of the plenary meeting for the recapitulation of the vote count went smoothly. The organizer's services in the form of arrangements for everyone present were carried out strictly in accordance with health protocols through the gates of the KPU of Bandung Regency office which were tightly guarded. The seating arrangements have been arranged in such a way that everyone present can attend the plenary meeting properly. There were challenges for organizers at all levels to consistently apply health protocols, as a real answer to those who worried about the emergence of local election clusters during a pandemic.

In addition, two large tents were carried out properly in accordance with the provisions of health protocols. There is a neat seating arrangement for PPK members, sub-district supervisory committees, local government officials, observers, mass media and other invited guests. Television screens were also installed that were connected from the plenary meeting room to provide a comfortable atmosphere for the press, monitoring institutions, regional governments, and other invited parties to participate in the entire series of activities. This was important because it relates to the public information disclosure.

Services in the form of seating arrangements in a special room for plenary meetings were also carried out in a neat and orderly manner, for the five commissioners of The KPU of Bandung Regency, as well as seats for witnesses from pairs of candidates, Regency Supervisory Agency/Panwas and PPK members who take turns reading the recapitulation results. Likewise, the arrangement of the ballot boxes was arranged properly and neatly so that the existence and arrangement of the layout of the plenary meeting room which was neatly arranged was an asset for the process of circulating people and documents to facilitate the recapitulation stage.

The recapitulation stage in general went smoothly, starting with the opening ceremony by the Chairperson of The KPU of Bandung Regency. The presentation of the recapitulation results in turn was delivered by PPK in the Bandung Regency, which was then also responded by witnesses from candidate pairs, which also went smoothly. There was a debate between the parties, especially between the witnesses from the candidate pair and the Bandung Regency Supervisory Agency/Panwas. As a political process, of course, this fact was normal.

Local election organizers during the plenary meeting provide an opportunity for the parties to correct this recapitulation of the vote count. Services in the form of broad and open access for users of information as well as free opportunities, especially for supervisory agency and witnesses from pairs of candidates to express different attitudes and opinions, were an important part of efforts to realize democratic elections. Supported by the participation of monitoring institutions, was the driving force behind the emergence of legitimacy for the elections.

Regarding the results of the recapitulation, namely pair number 1 received 511,413 (30.85\%), serial number $2(217,780,13,14 \%)$, and serial number $3(928,602,56.01 \%)$, there was a request for dispute over election results from pair number order 1 to the Constitutional Court (MK). After going through two trials, the institution decided that the applicant's application could not be accepted. The next organizer service after the determination of the selected pair of candidates in the plenary meeting held on March 20, 2021 submit the decision document at the plenary meeting, and to the Bandung Regency DPRD on 
Public Service Transformation During The Covid 19 Pandemic by The General Election Commission of Bandung ... Tatang Sudrajat

March 21, 2021 to ratify the appointment of the elected candidate pair.

Based on the results of the recapitulation of votes at the district level, data showed that the level of community participation in the 2020 elections was $72.18 \%$, which means there was an increase of $9.28 \%$ compared to the 2015 elections which were $62.90 \%$. Another important thing as a service provided by the organizers to the local election stakeholders was the evaluation meeting of the implementation of the local elections inviting various related parties on March 30, 2021. This was very important because more objective suggestions/inputs/corrections/recommendations obtained to improve the implementation of elections in the future. This means that the services provided to the community and other parties will be better.

\section{Logistics Service}

The logistics services of the organizers were mainly aimed at adhoc implementers at the subdistrict, village and TPS levels. The provision and distribution of various types of logistics, both the main ones in the form of ballot papers, ballot booths and various recapitulation forms, as well as other logistics, including personal protective equipment and health protocol logistics, were managed by the local election organizers with the availability of two main warehouses at The KPU of Bandung Regency. This type of health protocol logistics includes face shields, medical masks, cloth masks, latex gloves, plastic gloves, thermo guns, hazmat suits, plastic trash bags, hand sanitizers, disinfectants, sprayers, hand washing facilities, liquid soap and tissues.

The various breakthroughs made by the local election organizers, especially in logistics management, certainly cannot be separated from the continuous demands from the community for more quality services in their implementation. In the context of globalization, Rewansyah has reminded that one of the strategies that need to be pursued by administrative institutions was to improve the quality of public services (Rewansyah, 2010).

\section{Monitoring, Survey and Quick Count Service}

Organizer services provided to institutions that carry out monitoring, surveys, and quick counts as a form of public participation in the elections, in the form of registration announcements, can be accessed through The KPU of Bandung Regency website, among others. The registration mechanism served offline and online after the verification of required documents, a certificate was issued as a monitoring agency, survey/poll and quick count.

Some of the certificates submitted to these institutions were carried out offline at the secretariat of the regional head elections, while others were submitted online/online. Likewise, the submission of reports on activities that have been carried out by these institutions, was submitted online and offline. This change was indeed a logical consequence of environmental changes, in the form of the Covid-19 outbreak. Henry suggests that environmental changes can have such profound effects that organizations will radically transform themselves to survive in an altered environment (Henry, 2015)

Domestic monitoring institutions that have received monitoring certificates were the Bandung Regency Voters Education Network (JPPR), West Java KPK, Bandung Regency Secretariat, and FISIP Sangga Buana University YPKP Bandung. There was only one polling agency, namely PT KIO Sembilan Lima (Kedai KOPI). The quick count institutions were the Indonesian Voice Network (JSI), the Indonesian Survey Circle Communication Image (Cikom LSI) and the Indonesian Political Indicator.

\section{Challenges and Problems}

The KPU of Bandung Regency as the organizer for four times conducted blended system with strict health protocols facing several challenges and problems.

Changes in the service mechanism provided, both to internal parties, namely adhoc implementers and external parties, namely the voting community and political parties, from mostly offline to mostly online, resulted in a change in the pattern local election message communication. Even though an online explanation has been given, some stakeholders still want to meet faceto-face with the local election organizers. Various technical provisions to tighten services at the local election stage by implementing health protocols, were faced with the fact that it was not an easy thing to change the habit of communicating face to face.

The use of information technology facili- 
J1AD: Jurnal Ilmu Administrasi dan Pemerintahan Indonesia Volume 02 No 02 December 2021

Pages 81-91

ties in improving services at all stages of the local election, not only because of the Covid-19 outbreak, but also because of the demands of the industrial revolution 4.0 era. All local election officials must be fully aware that globalization has also brought about fundamental changes that require a transformation of government systems and mechanisms. The capacity of information technology hardware available in providing services was also not fully adequate. Arfah's research on the election in Makassar shows that one of the obstacles in service during the election was the lack of supporting facilities and infrastructure(Arfah, 2021)

Services to candidatepairs/campaignteams during several stages of the election still indicate disproportionality, amid pressure from various groups so that election organizers can maintain their neutrality and impartiality(Muhlis, 2021). In this regard, the integrity of the organizers was very significant for the performance of services as expected by the public. The motivation of the organizers as public servants will be of public concern. In this regard, Stillman II suggests that a public service motive was a type of human need. The desire to fulfil human needs influences of behaviour. Public service motives have the potential for advancing the democratic state, but they also were the heart of a fundamental tension with key tenets of administrative behaviour (Stillman \& Raadschelders, 2010)

In the current era of transparency and accountability, all public institutions, including election organizers, must increase their responsiveness to public aspirations because they were continuously controlled by the public. According to Fessler and Donald F. Kettl, one of the characteristics of the public process was public scrutiny. To a far greater degree than in the private sector, public administrators work under public scrutiny (Kettl, 2016). On the other hand, the incessant concern and pressure from some parties for the election to be postponed again or even postponed, because of the Covid-19. Muhlis argued that holding elections during the pandemic caused a psychological burden, anxiety, insecurity, and anxiety on the organizers, thus having an impact on the quality of work (Gerston, 2014)

The use of information technology in all stages of the local election, especially those that were directly in contact with the interests of voters and political parties, must always improve the quality of their services. James E. Switzerland suggests that in the context of Total Quality Management, quality was achieved only when managers create an organizational culture that focuses on consistently producing quality products and then on improving them every period (Rosenbloom, Kravchuk, \& Clerkin, 2009) This will further enrich the forms of public services that have been running so far, such as e-government and e-procurement in order to provide faster, better, and cheaper public services.

\section{CONCLUSION}

The stages of the simultaneous national elections in 2020, including in Bandung Regency, which were originally designed as has been carried out in the previous three local elections, underwent major changes due to the Covid-19 pandemic. Most of the local election stages, which were carried out especially those related to external parties, were a form of public service. Among them were updating voter data, socialization and voter education, nomination of candidate pairs, campaigning as well as voting and counting votes. Thus, there was a transformation of public services that rely on communication and information technology.

As the organizer of the local election of the regent and deputy regent, The KPU of Bandung Regency in addition to referring to various regulations from the KPU, has also made many breakthroughs in its implementation at various stages. This not only has implications for the effectiveness of targets at each stage of the local election, but also encourages efforts to prevent the spread of Covid -19. As an organizer, The KPU of Bandung Regency were also faced with various challenges and problems, both internal and external, which have an impact on several activities at the local election stage.

\section{ACKNOWLEDGEMENT}

Thank you to the Chairperson of The KPU of Bandung Regency and his staff who have helped provide data for this research. Also to Bawaslu, the JPPR monitoring agency, members of the campaign team, and the Head of PPK who have provided adequate data in this research. Thanks, are also conveyed to the Director of LPPM, Sangga Buana University, Bandung, who has facilitated this research. 
Public Service Transformation During The Covid 19 Pandemic by The General Election Commission of Bandung ... Tatang Sudrajat

\section{REFERENCES}

Arfah, S. R. (2021). Penilaian Kinerja Panitia Pemilihan Kecamatan (Ppk) Bontoala Dalam Penyelenggaraan Pemilihan Walikota Dan Wakil Walikota Makassar Tahun 2020. Journal I La Galigo| Public Administration Journal, 4(1), 1-9.

Bahriyah, E. N., \& Afif, A. S. (2021). Partisipasi Masyarakat dan Penerapan PKPU No. 6 Tahun 2020 menuju Pilkada Serentak 2020 pada Masa Pandemi Covid19. KOMUNIKOLOGI : Jurnal Ilmiah Ilmu Komunikasi, 18(6).

Cooper, P.J., Taylor, M.J., Cooper, Z. and Fairbum, C.G. (1987), The development and validation of the body shape questionnaire. Int. J. Eat. Disord., 6: 485-494. https://doi. org/10.1002/1098-108X(198707)6:4<485::AIDEAT2260060405>3.0.CO;2-O.

Gerston, L. N. (2014). Public policy making: Process and principles. Routledge.

Henry, N. (2015). Public administration and public affairs. Routledge.

Kettl, D. F. (2016). Politics of the administrative process. Cq Press.

Muhlis, M. (2021). Polemik Pilkada 2020 Di Masa Pandemi Covid-19: Antara Demokrasi Dan Oligarki. Ganaya: Jurnal Ilmu Sosial Dan Humaniora, 4(1), 116-141.

Rewansyah, A. (2010). Reformasi Birokrasi Dalam Rang$k a$ Good Governance. Yusaintanas Prima.

Rosenbloom, D. H., Goldman, D. D., \& Ingraham, P. W. (1994). Contemporary public administration. McGraw-Hill Humanities, Social Sciences \\& World Languages.

Rosenbloom, D. H., Kravchuk, R., \& Clerkin, R. M. (2009). Public administration: Understanding management, politics, and law in the public sector. Rout- ledge.

Rulinawaty, Samboteng, L., Aripin, S., Kasmad, M. R., Harta, R., Susanti, A., \& Fadillah, S. (2021). Accountability Performance Public Service: Community Based Organization Solution for Base Public Service. Proceedings of the First International Conference on Science, Technology, Engineering and Industrial Revolution (ICSTEIR 2020), 536(Icsteir 2020), 238-243. https://doi.org/10.2991/ assehr.k.210312.037

Stillman, R. J., \& Raadschelders, J. C. N. (2010). Goodbye with thanks and welcome aboard. Public Administration Review, 70(1), 7. https://doi.org/10.1111/ j.1540-6210.2009.02128.x

Tjiptono, F. (2005). Principles of Total Quality Service. Yogyakarta: Andi, 4.

Widhiasthini, N. W. (2020). Praktek Disrupsi Kampanye Pilkada 2020 dan Potensi Pelanggaran Kode Etik. Jurnal Etika dan Pemilu, 6(1), 96-104.

UU Nomor 1 Tahun 2005 tentang Penetapan Perpu Nomor 1 Tahun 2014 tentang Pemilihan Gubernur, Bupati, dan Wali Kota menjadi Undang-Undang

UU Nomor 17 Tahun 2007 tentang Rencana Pembangunan Jangka Panjang 2005-2025

UU Nomor 7 Tahun 2017 tentang Pemilihan Umum

Peraturan KPU Nomor 15 Tahun 2019 tentang Tahapan, Program dan Jadwal Penyelenggaraan Pemilihan Gubernur dan Wakil Gubernur, Bupati dan Wakil Bupati dan/atau Walikota dan Wakil Walikota Tahun 2020

Peraturan KPU Nomor 6 Tahun 2020 tentang Pelaksanaan Pemilihan Gubernur dan Wakil Gubernur, Bupati dan Wakil Bupati, dan/atau Walikota dan Wakil Walikota Serentak Lanjutan dalam Kondisi Bencana Non Alam Covid 19 